\title{
Narrowing the Gap Between Publication and Access: is a Mandate Enough to Get Us Closer?
}

\author{
Maria Manuel Borges \\ Faculty of Letters of the University of Coimbra, Largo da Porta Férrea, 3004-530 Coimbra, Portugal, Tel. +351239859900, Fax \\ +351239836733, mmb@fl.uc.pt \\ António Tavares Lopes \\ Faculty of Letters of the University of Coimbra, Largo da Porta Férrea, 3004-530 Coimbra, Portugal, atlopes@ fl.uc.pt
}

\begin{abstract}
Changes brought about by the Internet to Scholarly Communication and the spread of Open Access movement, have made it possible to increase the number of potential readers of published research dramatically. This two-phase study aims, at first, to assert the satisfaction of the potential for increased open access to articles published by authors at the University of Coimbra, in a context when there was no stimulus for the openness of published science other than an institutional mandate set by the University policy on Open Access ("Acesso Livre"). The satisfaction of the access openness was measured by observing the actual archiving behavior of researchers (either directly or through their agents). We started by selecting the top journal titles used to publish the STEM research of the University of Coimbra (2004-2013) by using Thomson Reuters' Science Citation Index (SCI). These titles were available at the University libraries or through online subscriptions, some of them in open access (21\%). By checking the journals' policy at the time regarding self-archiving at the SHERPA/RoMEO service, we found that the percentage of articles in Open Access (OA) could rise to $80 \%$ if deposited at Estudo Geral, the Institutional Repository of the University of Coimbra, as prescribed by the Open Access Policy of the University. As we concluded by verifying the deposit status of every single paper of researchers of the University that published in those journals, this potential was far from being fulfilled, despite the existence of the institutional mandate and favorable editorial conditions. We concluded, therefore, that an institutional mandate was not sufficient by itself to fully implement an open access policy and to close the gap between publication and access. The second phase of the study, to follow, will rescan the status of published papers in a context where the Portuguese public funding agency, the Fundação para a Ciência e a Tecnologia, introduced in 2014 a new significant stimulus for open access in science. The FCT Open Access Policy stipulates that publicly funded published research must be available as soon as possible in a repository of the Portuguese network of scientific repositories, RCAAP, which integrates the Estudo Geral.
\end{abstract}

\section{Keywords:}

Open Access; Institutional Repositories; Institutional Mandates; Self-archiving; Estudo Geral

\section{Highlights}

- Core STEM authors of the University of Coimbra have high exposure to OA editorial practices.

- Given journals policies regarding self-archiving, OA can be extended to cover a large proportion of all published research.

- Widening access to published research, however, does not represent a significant concern for authors.

- An institutional mandate is not sufficient, per se, to assure wide dissemination of open research.

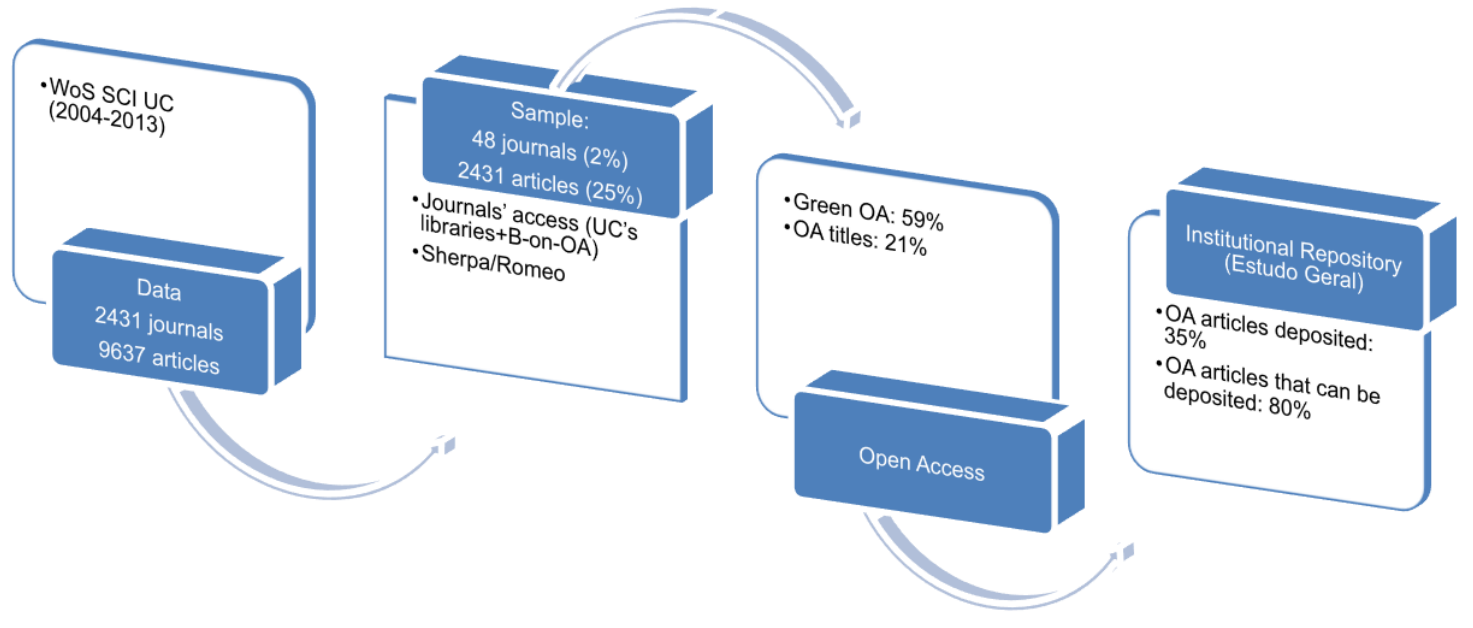

Graphical Abstract 


\section{INTRODUCTION}

The origins of scientific articles go back to the 17th century when the "Philosophical Transactions of the Royal Society of London" was first published with the purpose to create "a public record of original contributions to knowledge" (Guédon, 2001). Soon, however, this 'public record' took on other and crucial functions: "registering the ownership of scientific discovery and of 'packing down' current communication into an indexed, readily usable archive" (Schauder, 1994, p. 75). On the 19th century, its functions were again amplified because "publication of articles of journals came to be seen as the prime indication of the professional standing of research professionals and the organization that employed them" (Schauder, 1994, p. 75). For scientists, the reward for publication is recognition: "they make contributions to the knowledge in the expectation of receiving recognition by the community" (Ziman, 2002, p.45), or attention: "success in science is rewarded with attention. You gain full membership in the scientific community only by receiving the attention of your fellow scientists" (Franck, 1999), a very complex issue, pointed, among others, by Latour \& Woolgar (2013, p. 189-233).

Since communication is a core activity in science, any change is of extraordinary importance. The Internet and electronic publishing brought a shift to scholarly communication, opening up new channels, opportunities, and challenges: "As opposed to "traditional" science that does without networked computers, the notion of "cyberscience" captures the use of these ICT-based applications and services for scientific purposes" (Nentwich, 2003, p. xix). New forms of production, collaboration, and dissemination of information thrive new channels of Scholar Communication: Open Access (OA) to articles and data, licensing of information (Creative Commons), collaboration (ResearchGate, Academia.edu), and discovery (Mendeley, CiteULike).

\section{PROBLEM STATEMENT}

The new landscape of scientific information extends dissemination channels either through formal publication, e.g., journals or through informal dissemination of information, e.g., institutional or thematic repositories. The electronic publication made possible the setting of repositories of all kinds, which are available for researchers, students, and society in general. For every stakeholder, these are opportunities that can open science, and new experiments are already taking place not only regarding new formats for publishing but also on peer review, alternative or complementary metrics, among others.

If scientific information can (or cannot) have wide dissemination is a decision that concerns institutions and researchers and one that can have a positive or negative impact on their rankings and careers. With the extraordinarily high volume of publications that are in place today, it became difficult if not impossible for a university to afford all the titles for all the disciplines that every researcher needs. The consequences of this barrier are clear: "all articles are currently losing some portion of their potential research impact (usage and citations) because they are not accessible online to all their potential users" (Gargouri et al., 2010).

At the same time, and to a great extent, lifting this barrier is in authors' hands, either by selecting open access journals for the publication of their research or by making a version of their work openly available after publication.

In the present study, we seek to understand (i) how access to resources frames the selection of journal for publication, and (ii) if authors or their agents effectively realized the potential for increased access to the articles published by the researchers, that is, if broader open access to the published research is a visible concern for authors.

We conducted our data collection in what could have been expected to be a highly favorable environment for openness, one in which the academic institution formally stated policy on open access, and an institutional repository was fully operational.

Our study is a contribution to establish if the setting of such favorable environments is sufficient to narrow the gap between production and wide access. This understanding is instrumental to the actual formalization of policies that institutions may carry to increase the exposure to their research, which is, ultimately, bound to their attractiveness and relevance.

\section{LITERATURE REVIEW}

The openness of scientific communication, whose advantages have been pointed out in several studies and reports (e.g., Willinsky, 2005; Davis, 2011; Royal Society (Great Britain), \& Policy Studies Unit. (2012), is based on the social and ethical perspectives that regard the free availability of the results of scientific research not only as a moral imperative but also as an answer to the progressive accountability of science, particularly when paid by public money.

At the root of the freeing of scientific literature, one can find the so-called 'serials crisis,' an expression that resumes the high prices of scholarly journals that universities' libraries can no longer afford since the late 1980s. For Panich and Michalak (1995) this is a symptom of a wider problem in the scholarly communication system who compromises access to research and whose consequences for authors and readers became severe, with losses for both parts. On the one hand, 
readers could not read, and therefore cite, the articles published, and authors could not get recognition, through citation, to what they published.

In 1990, Stevan Harnad wrote a 'subversive proposal,' a call to action for the authors to regain control over their works (Harnad, 1990). In 14th February 2002, the Budapest Open Access Initiative (BOAI) was the first of a series of declarations - Berlin and Bethesda, among others worldwide -, giving birth to OA to the scientific literature as an answer to the scholarly communication crisis. On this article we will adopt the definition of Peter Suber (2012, p. 4): "Open Access (OA) literature is digital, online, free of charge, and free of most copyright and licensing restrictions." OA to scientific information was made possible by the Internet technologies and applications, mainly because these technologies lowered the costs, if not of the publication itself, at least of its electronic distribution. Open science also means that its results are freely available, which extends the community of researchers that uses them and, ultimately, references them and cites them. Even if there is no ethical or social impulse driving an author to publish his or her work under OA, there is a clear benefit of it. OA increases the possibility of a work to be known, read, used and cited, as several studies have been proving for a long time (Lawrence, 2001, Antelman, 2004, Brody et al., 2004; Brody, Harnad, \& Carr, 2006; Eysenbach, 2006; Harnad et al., 2004; Piwowar, Day, \& Fridsma, 2007). Each one of these phases adds value to the published result, the researcher recognition, and the impact of the work. Pressed directly or indirectly by researchers, institutions, and funding agencies, publishers have been forced to clarify their policies regarding the openness of their journals. In many cases, this resulted in publishers allowing for some form of an accessible version of the published works.

Self-archiving, as defined by Bjork et al. (2014), does not affect the perceived quality of the editorial process, since it can occur after publication. Because it does not present any risk of strengthening negative perceptions towards editorial and reviewing quality that authors and other stakeholders may associate with OA, self-archiving is instrumental in lifting the barriers to access, when they exist. Therefore, self-archiving awareness, motivation, and behavior have been relevant subjects of research in recent OA studies. Most of this research was conducted based on surveys to assess authors perceptions on different aspects: on a given discipline (e.g. Pelizzari, 2003; Antelman, 2006; Voronin, Myrzahmetov, \& Bernstein, 2011; Mischo \& Schlembach, 2011; Hahn, 2014; Migheli \& Ramello, 2014; Hahn \& Wyatt, 2014, Graziotin, 2014), on an university (Borges, 2006; Kim, 2010; Kim, 2011; Miguéis, 2012;); or on a broader vision (country, Europe, World) (Swan \& Brown, 2004; Nicholas, Huntington, \& Rowlands, 2005; Fry et al. 2009; Creaser, 2010, Creaser et al. 2010). One may find a synoptic table of some of these, and other studies in Togia \& Koroboli (2014).

Concerning self-archiving practices when there are institutional mandates, Spezi et al. (2013), in a study grounded on focus groups and multi-phased European-wide surveys that supported the PEER project - Publishing and Ecology of European Research, noticed that while self-archivers are predominantly motivated by the expectative of dissemination increase of their work, an institutional mandate does not usually trigger self-archiving awareness. Institutional mandates are considered relatively irrelevant, as a motivation factor, and viewed as "insufficiently enforced." Other reports on the first phases of the project had already established that only a small percentage of researchers associate self-archiving to OA (Creaser et al., 2010). Researchers regard the repository as the only evidence of institutional access policy and usually confused with it. The lack of visibility and hard to find documentation must contribute to the unawareness of the policy and consequent weakness of the institutional mandate enforcement (Creaser, 2010; Miguéis, 2012). Gargouri et al. (2010) found the opposite, i.e. that there is a significant correlation between mandate strength and the ratio of selfarchiving submissions.

Concerning copyright permissions and self-archiving, Laakso (2013) developed a study having Scopus as the source database. There he identified the 100 largest publishers responsible in terms of articles published (68\% of articles published per year). The results were then searched in the SHERPA/RoMEO database to find that most of them could be on OA: $62 \%$ immediately upon publication. An earlier study concerning the publication of the University of Coimbra (UC) in 2006 using Web of Science (WoS), Science Citation Index (SCI) as the source database (Borges, 2006), concluded about the same: most of the titles used by authors from UC where published on green publishers (77\%). While using the same source, Hansen (2012) found that a significant percentage of the more than 29 thousand articles of the period studied were susceptible to archiving with little or no author intervention. Antelman (2006) and Covey (2009) also found that there is no connection between self-archiving practices and publishers' policies. Like other studies (e.g., Borges, 2006; Creaser et al. 2010; Fry et al. 2009), it is on a disciplinary level that we can find an understanding of selfarchiving behavior.

The fact that publication relates to the reward system makes researchers very cautious when selecting where to publish. It is interesting to note that "young scholars can be particularly conservative in their research dissemination behavior and that established scholars can afford to be the most innovative with regard to dissemination practices" (Harley et al., 2010, p. 13), and because of this, one can not expect younger researchers to have the initiative to select other channels, eventually more familiar to them. However, one should note that the potential for dissemination and attention, measurable trough citations, does not ask for a change in the publication venue. 


\section{METHODS}

The academic community has access to scientific information at the UC through physical and Web resources. The research units, departmental and central libraries of the university, specialized databases, and B-on, a national-wide subscription consortium that intermediates access to some of the major international scientific publishers and services, support the availability of those bibliographic resources.

In order to identify the most relevant titles for UC's authors, we selected the Thomson Reuters SCI database as the primary information source. Although this selection put aside contributions of Social Sciences and Arts and Humanities authors, which are covered, in WoS, by different indexes (Social Sciences Citation Index - SSCI and Arts and Humanities Citation Index - A\&HCI, respectively), it gave us a coherent starting point. The data set has consistent, broad, and in-depth coverage of the scientific fields addressed by the index (STM - Science, Technical, and Medical). Furthermore, we assume that some known biases of the WoS databases are less relevant and prejudicial in STM areas than it is in the Social Sciences, Arts and Humanities.

Data gathering was a 5-step process that took place in June 2015. First, we queried the WoS Core database for records in which researchers of the UC contribute as authors. The identification of author affiliation was made based on the appropriate Organization-Enhanced WoS field value. A temporal filter from 2004 to 2013 - the first decade of B-on operative service - was applied to this query. Other filters restricted the result set to records that are indexed by SCI and refer to articles, excluding those published in book series. We then requested the WoS search service for an analysis report based on the source, that produced a list of 2431 journal titles, referring to 9637 records.

Next, a selection process inspired by Bradford's Law narrowed this result set even further, to establish the core journals for the UC STM authors, under the WoS perspective. We applied this principle to the SCI report, which allowed us to establish the sample by identifying the top 48 journals $(2 \%)$ responsible for the publication of one-quarter of the articles $(25 \%)$.

We determined the access conditions of authors to these selected titles by checking the title records in the UC's library catalog, their availability through B-on subscribed services, or as open access publications. This process established, for each one of the selected titles, what methods of access were relevant for the University community during the observed period: either a paid local subscription for a print and online edition, or a paid subscription in a consortium, or as a Web service, or a freely available Web resource.

We verified the policy of non-OA titles regarding copyright and self-archiving by consulting the journal records in the SHERPA/RoMEO database. This step allowed establishing the potential for broad, full access to the published scientific production of the University STM authors in core journals.

Finally, we verified if authors archived a post-print or final version of articles published in Green OA journals, that is, in subscription-based journals that authorize a phase-two manuscript self-archiving. This last verification was fundamental to understand if authors or their agents fulfilled the previously asserted open access potential. It was carried on by consulting the institutional repository database and by establishing the records corresponding to articles, in case a document has been archived or, at least, a reference has been made by authors or by an agent on their behalf. That is, instead of measuring authors' perceptions and projected attitudes, as targeted by the survey-based studies that we mentioned in the literature review, our study measures expressed behavior.

We plan to repeat this procedure in the second phase of this investigation after five years have passed since the Portuguese public funding agency, the Fundação para a Ciência e Tecnologia, introduced the requirement for OA to all funded published research, including the archiving in one of the repositories of the National network of OA academic repositories.

\section{RESULTS AND DISCUSSION}

In Table 1, we show the top journals that host 25\% of the 2004-2013 production of the University STM authors and that are indexed by Thomson Reuters in SCI. Most of these journals are international publications, the exception being those in Medicine fields, which are published by local Portuguese medical associations. Physics and Chemistry are the fields with more prominent representation in the table and occupy the leading spots.

All but two of these titles are available in some traceable form to the authors, during the considered period, as shown in Table 2. The weight of local subscription by a departmental library was noticeable, as it was also the case of access by the B-on consortium. By the end of the observation period, some of the local subscriptions terminated since the nationalwide consortium started to provide access to these titles and the associated cuts in costs are significant to the libraries budgets. Another reason for the termination of a subscription was the change in the access policy of specific publications, which turned into open access journals during the period of observation.

An aspect of high significance is the weight of OA articles authored by the University researchers. Overall, in the period of observation, OA articles account for $21 \%$ of all published articles. This number contrasts with what SCI reported for its entire index, during the same period: OA represented by then only $8 \%$ of the over 10 million articles indexed by SCI. That is, University researchers in the STM fields publish their work in open access titles more than two and a half times the general percentage found in all SCI. 
Although one-fifth of articles in OA was already a substantial and exceptional figure, this value had a potential growth even without changing conditions of production, that is, without changing the set of journals to which authors of the University submitted their articles. Self-archiving, the possibility that publishers grant an author to make a copy of his or her work openly available, in a personal website or institutional repository, nurtures that potential. Depending on the terms defined by each publisher, the copy may be an exact copy of the published work, or an interim copy, before or after the process of editorial revision (pre or post-print).

One of the concerns frequently mentioned by researchers is the risk of infringement of the publisher's copyright. It is, therefore, crucial to verify the validity of this concern in the face of the publishers' policies. We used SHERPA/RoMEO, a service that registers journals policies towards copyright and self-archiving, to determine the potential growth of openness of the UC STM core journals. Publishers' permissions were coded by a color in the SHERPA/RoMEO database and summarized in Table 3.

The distribution of the top journals in which the University STM authors published, according to their SHERPA/RoMEO classification, is shown in Table 4. The combined figures of Green journals and Open Access journals indicate that the full potential for OA was then close to $80 \%$. This sum means that not just one but up to four-fifths of top production from the University of Coimbra STM authors could have been made freely available, without special effort or expense, and, very importantly, without affecting the selection of publication targets in regard of their openness or editorial practices. Our findings are similar to those obtained by Borges (2006), Hansen (2012), and Laakso (2014), and by other authors in different contexts. Since the majority of the publishers granted authors the right to self-archive their articles in their personal Webpage or the institutional repository, open access to this scientific production would depend solely on the will and behavior of the authors.

In the case of the University of Coimbra, another significant factor favored the scenario for open science. The University of Coimbra Senate established, in 2010, an Open Access Policy that states mandatory self-archiving for all University research. According to this institutional mandate, open access to the archived material should be attained, whenever possible (a transcript of the text of this resolution, in Portuguese, is available at https://estudogeral.uc.pt/politica.jsp). Even when publishers, funders, or other interested parties do not allow authors to make a copy of their work openly available, the Open Access Policy of the University states that authors must submit an embargoed non-public version of their scientific production in the University's repository. Additionally, a complete metadata record must accompany the stored copy. To help on the materialization of this policy, the University gave its authors the means to publish their copies in an institutional repository, named 'Estudo Geral,' launched in June 2008. Complementary, authors also benefited from departmental and central support teams to help with the archiving of their work.

Two years after the publication of the institutional mandate of the University, another study gathered new data about the attitude and perception of the authors (Miguéis, 2012). This study allowed the conclusion that, in the face of the answers obtained, the awareness of the repository and the institutional mandate were still deficient. Looking at the results, although authors have the right, the duty, and the means, they fail short of fulfilling the openness potential of their published research.

As Table 5 shows, 77\% of articles published by the University STM authors in top journals that had a green policy towards self-archiving, were not archived in the institutional repository and not made openly and freely available, as they could have been. When we sum Green self-archived articles and original OA articles, we have a measure of the OA exposure: instead of $80 \%$, authors only archived $34,75 \%$ of all articles that could have been made freely on the repository of the University.

The figures we gathered, in conjunction, represent a mirrored model of the access-production-access information cycle. In this model, authors passively rely on the closed channels of communication provided by the journals and disregard the potential for wider dissemination of their work that self-archiving permits, at least through institutional repositories. Distribution does not alter access conditions, which remain the same that precedes production. On the other hand, a prismatic model widens the access conditions of the published work. In such a model, authors actively seek better access conditions than those they found while producing their texts, following the expectation that wider access increases impact or matches the requirements of social responsibility of science.

Given the high proportion of articles of the University STM authors published in OA journals, we could expect that these numbers had roots on a cultural standpoint supportive of Open Access. However, in the face of the weak fulfillment of the openness potential, the explication of that proportion has to be found elsewhere. Support for OA differs by epistemic areas, and the choice for publication in an OA does not necessarily correspond to an active perspective on Open Access. Since the top OA journals targeted by the University STM authors cover medical and physics studies, and, in the case of medical journals, are published by Portuguese associations, both of the above factors must converge to set the proportion we found.

\section{CONCLUSION}

Electronic publishing and the opportunities brought by the Internet opened up new channels for broader dissemination of information, including scientific information. Communication is a core activity for science in the sense that it is a crucial process with the purpose of open discussion, certification, ownership attribution and recognition of the quality of 
research. The reward is one indicator of the influence that each research/research group can have to the progress of science, measured by the impact obtained through citations.

Major public research funding organizations, including the European Commission since 2012, have already taken a position: within a possible but limited period of embargo, the archive of all published research funded by public grants in Institutional Repositories is becoming mandatory. In Portugal, the Fundação para a Ciência e Tecnologia, the public funding agency, adopted, since May 2014, the same policy, which is expected to have a positive impact on the percentage of OA items, as we plan to investigate in the follow-up of this work.

This study shows that while the University of Coimbra had already a sound exposure to OA, which was above the average in SCI, the OA dissemination of its production could have risen significantly to $80 \%$, with just the adoption of self-archiving. Despite the presence of an institutional mandate, the satisfaction of the OA potential failed short, as the institutional mandate proved to be insufficient to trigger a comprehensive self-archiving behavior.

\section{REFERENCES}

Antelman, K. (2004). Do Open-Access Articles Have a Greater Research Impact? College \& Research Libraries, 65(5), 372-382. http://doi.org/10.5860/crl.65.5.372

Antelman, K. (2006). Self-archiving practice and the influence of publisher policies in the social sciences. Learned Publishing, 19(2), 85-95. Retrieved from http://www.ingentaconnect.com/content/alpsp/lp/2006/00000019/00000002/art00002

Björk, B.-C., Laakso, M., Welling, P., \& Paetau, P. (2014). Anatomy of green open access. Journal of the Association for Information Science and Technology, 65(2), 237-250. http://doi.org/10.1002/asi.22963

Borges, M. M. (2006). A Esfera: Comunicação Académica e Novos Media. Faculdade de Letras, Coimbra. Retrieved from http://hdl.handle.net/10316/8557

Brody, T., Harnad, S., \& Carr, L. (2006). Earlier web usage statistics as predictors of later citation impact. Journal of the American Society for Information Science and Technology, 57(8), 1060-1072.

Brody, T., Stamerjohanns, H., Vallières, F., Harnad, S., Yves, G., \& Charles, O. (2004). The effect of open access on citation impact. Serials Review.

Covey, D. T. (2009). Self-Archiving Journal Articles: A Case Study of Faculty Practice and Missed Opportunity. Portal: Libraries and the Academy, 9(2), 223-251. http://doi.org/10.1353/pla.0.0042

Creaser, C. (2010). Open Access to Research Outputs-Institutional Policies and Researchers' Views: Results From Two Complementary Surveys. New Review of Academic Librarianship, 16(1), 4-25. http://doi.org/10.1080/13614530903162854

Creaser, C., Fry, J., Greenwood, H., Oppenheim, C., Probets, S., Spezi, V., \& White, S. (2010). Authors' Awareness and Attitudes Toward Open Access Repositories. New Review of Academic Librarianship, 16(sup1), $145-161$. http://doi.org/10.1080/13614533.2010.518851

Davis, P. M. (2011). Open access, readership, citations: a randomized controlled trial of scientific journal publishing. The FASEB Journal, 25(7), 2129-2134. http://doi.org/10.1096/fj.11-183988

Eysenbach, G. (2006). Citation Advantage of Open Access Articles. PLoS Biology, 4(5), e157-e157. http://doi.org/10.1371/journal.pbio.0040157

Franck, G. (1999). Scientific Communication - A Vanity Fair? Science, 286(5437), 53-55. http://doi.org/10.1126/science.286.5437.53

Fry, J., Oppenheim-DIS, C., Creaser, C., Johnson, W., Summers, M., White-LISU, S., ... Hartley-CERLIM, D. (2009). Communicating knowledge: How and why researchers publish and disseminate their findings. JISC.

Gargouri, Y., Hajjem, C., Larivière, V., Gingras, Y., Carr, L., Brody, T., \& Harnad, S. (2010). Self-Selected or Mandated, Open Access Increases Citation Impact for Higher Quality Research. PLoS ONE, 5(10), e13636-e13636. http://doi.org/10.1371/journal.pone.0013636

Graziotin, D. (2014). Green open access in computer science - an exploratory study on author-based self-archiving awareness, practice, and inhibitors. ScienceOpen Research, 1-11. http://doi.org/10.14293/A2199-1006.01.SORCOMPSCI.LZQ19.v1

Guédon, J.-C. (2001). In Oldenburg's Long Shadow: Librarians, Research Scientists, Publishers and the Control of Scientific Publishing. Washington, DC: ARL.

Hahn, S. E., \& Wyatt, A. (2014). Business Faculty's Attitudes: Open Access, Disciplinary Repositories, and Institutional Repositories. Journal of Business \& Finance Librarianship, 19(2), 93-113. http://doi.org/10.1080/08963568.2014.883875

Harley, D., Acord, S. K., Earl-Novell, S., Lawrence, S., \& King, C. J. (2010). Assessing the future landscape of scholarly communication: An exploration of faculty values and needs in seven disciplines. Berkeley, CA.

Harnad, S. (1990). Scholarly skywriting and the prepublication continuum of scientific inquiry. Psychological Science, 342-344. 
Harnad, S., Brody, T., Vallières, F., Carr, L., Hitchcock, S., Gingras, Y., ... Hilf, E. R. (2004). The access/impact problem and the green and gold roads to open access. Serials Review, 30(4), 310-314.

Hansen, D. (2012). Understanding and Making Use of Academic Authors' Open Access Rights. Journal of Librarianship and Scholarly Communication, 1(2). http://doi.org/10.7710/2162-3309.1050

Kim, J. (2010). Faculty self-archiving: Motivations and barriers. Journal of the American Society for Information Science and Technology, 61(9), 1909-1922. http://doi.org/10.1002/asi.21336

Kim, J. (2011). Motivations of Faculty Self-archiving in Institutional Repositories. The Journal of Academic Librarianship, 37(3), 246-254. http://doi.org/10.1016/j.acalib.2011.02.017

Laakso, M. (2014). Green open access policies of scholarly journal publishers: a study of what, when, and where selfarchiving is allowed. Scientometrics, 99(2), 475-494. http://doi.org/10.1007/s11192-013-1205-3

Latour, B., \& Woolgar, S. (2013). Laboratory life: The construction of scientific facts. Princeton University Press.

Lawrence, S. (2001). Free online availability substantially increases a paper's impact. Nature, 411(6837), 521-521. http://doi.org/10.1038/35079151

Migheli, M., \& Ramello, G. B. (2014). Open Access Journals and Academics’ Behavior. Economic Inquiry, 52(4), 12501266. http://doi.org/10.1111/ecin.12131

Miguéis, A. (2012). Atitudes e perceções dos autores depositantes do repositório científico da Universidade de Coimbra.

Mischo, W. H., \& Schlembach, M. C. (2011). Open Access Issues and Engineering Faculty Attitudes and Practices. Journal of Library Administration, 51(5-6), 432-454. http://doi.org/10.1080/01930826.2011.589349

Nentwich, M. (2003). Cyberscience: Research in the Age of the Internet. Vienna: Austrian Academy of Sciences Press.

Nicholas, D., Huntington, P., \& Rowlands, I. (2005). Open access journal publishing: the views of some of the world's senior authors. Journal of Documentation, 61(4), 497-519. http://doi.org/10.1108/00220410510607499

Panitch, J. M., \& Michalak, S. (2005). The serials crisis: a white paper for the UNC-Chapel Hill Scholarly Communications Convocation.

Pelizzari, E. (2003). Academic staff use, perception and expectations about Open-access archives: a survey of Social Science Sector at Brescia University. Retrieved from Academic staff use, perception and expectations about Openaccess archives: a survey of Social Science Sector at Brescia University

Piwowar, H. A., Day, R. S., \& Fridsma, D. B. (2007). Sharing Detailed Research Data Is Associated with Increased Citation Rate. PLoS ONE, 2(3), e308-e308. http://doi.org/10.1371/journal.pone.0000308

Royal Society (Great Britain), \& Policy Studies Unit. (2012). Science as an open enterprise. London: the Royal Society. Retrieved from https://royalsociety.org/ /media/Royal_Society_Content/policy/projects/sape/2012-06-20SAOE.pdf

Schauder, D. (1994). Electronic publishing of professional articles: attitudes of academics and implications for the scholarly communication industry. Journal of the American Society for Information Science, 45(2), 73-100.

Spezi, V., Fry, J., Creaser, C., Probets, S., \& White, S. (2013). Researchers' green open access practice: a crossdisciplinary analysis. Journal of Documentation, 69(3), 334-359. http://doi.org/10.1108/JD-01-2012-0008

Suber, P. (2012). Open access. Cambridge, Mass: MIT Press.

Swan, A., \& Brown, S. (2004). Authors and Open Access Publishing. Learned Publishing, 17(3), 219-224.

Togia, A., \& Korobili, S. (2014). Attitudes towards open access: A meta-synthesis of the empirical literature. In Let's Put Data to Use: Digital Scholarship for the Next Generation - Proceedings of the 18th International Conference on Electronic Publishing, ELPUB 2014 (pp. 13-22). http://doi.org/10.3233/978-1-61499-409-1-13

Voronin, Y., Myrzahmetov, A., \& Bernstein, A. (2011). Access to Scientific Publications: The Scientist's Perspective. PLoS ONE, 6(11), e27868-e27868. http://doi.org/10.1371/journal.pone.0027868

Willinsky, J. (2006). The Access Principle: The Case for Open Access to Research and Scholarship. Cambridge, Mass: MIT Press.

Ziman, J. (2002). Real science: What it is and what it means. Cambridge University Press. 
Table 1: Top list of journals in which University of Coimbra STM authors published by number of articles (2004-2013)

\begin{tabular}{|c|c|c|}
\hline Source Titles & Articles & $\%$ (Accum) \\
\hline PHYSICAL REVIEW D & 117 & $1.21 \%$ \\
\hline JOURNAL OF PHYSICAL CHEMISTRY A & 113 & $2.39 \%$ \\
\hline PHYSICAL REVIEW C & 108 & $3.51 \%$ \\
\hline NUCLEAR INSTRUMENTS METHODS IN PHYSICS RESEARCH SECTION A & & \\
\hline ACCELERATORS SPECTROMETERS DETECTORS AND ASSOCIATED EQUIPMENT & 101 & $4.56 \%$ \\
\hline PHYSICS LETTERS B & 100 & $5.59 \%$ \\
\hline PLOS ONE & 95 & $6.58 \%$ \\
\hline ACTA MEDICA PORTUGUESA & 78 & $7.39 \%$ \\
\hline PHYSICAL REVIEW B & 74 & $8.16 \%$ \\
\hline JOURNAL OF INSTRUMENTATION & 71 & $8.89 \%$ \\
\hline JOURNAL OF PHYSICAL CHEMISTRY B & 68 & $9.60 \%$ \\
\hline EUROPEAN PHYSICAL JOURNAL C & 65 & $10.27 \%$ \\
\hline ACTA CRYSTALLOGRAPHICA SECTION E STRUCTURE REPORTS ONLINE & 59 & $10.89 \%$ \\
\hline PHYSICAL REVIEW LETTERS & 58 & $11.49 \%$ \\
\hline IEEE TRANSACTIONS ON NUCLEAR SCIENCE & 58 & $12.09 \%$ \\
\hline ELECTROANALYSIS & 58 & $12.69 \%$ \\
\hline JOURNAL OF CHEMICAL PHYSICS & 56 & $13.27 \%$ \\
\hline SURFACE COATINGS TECHNOLOGY & 55 & $13.84 \%$ \\
\hline REVISTA PORTUGUESA DE CARDIOLOGIA & 51 & $14.37 \%$ \\
\hline ACTA REUMATOLOGICA PORTUGUESA & 50 & $14.89 \%$ \\
\hline ESTUARINE COASTAL AND SHELF SCIENCE & 48 & $15.39 \%$ \\
\hline TRANSPLANTATION PROCEEDINGS & 47 & $15.88 \%$ \\
\hline PHYSICAL CHEMISTRY CHEMICAL PHYSICS & 46 & $16.35 \%$ \\
\hline LINEAR ALGEBRA AND ITS APPLICATIONS & 46 & $16.83 \%$ \\
\hline JOURNAL OF HIGH ENERGY PHYSICS & 46 & $17.31 \%$ \\
\hline ECOLOGICAL INDICATORS & 42 & $17.74 \%$ \\
\hline JOURNAL OF MOLECULAR STRUCTURE & 41 & $18.17 \%$ \\
\hline REVISTA PORTUGUESA DE PNEUMOLOGIA & 41 & $18.59 \%$ \\
\hline CHEMICAL PHYSICS LETTERS & 40 & $19.01 \%$ \\
\hline LANGMUIR & 39 & $19.41 \%$ \\
\hline JOURNAL OF NEUROCHEMISTRY & 35 & $19.78 \%$ \\
\hline TETRAHEDRON & 33 & $20.12 \%$ \\
\hline PROGRESS OF THEORETICAL PHYSICS & 33 & $20.46 \%$ \\
\hline INDUSTRIAL ENGINEERING CHEMISTRY RESEARCH & 33 & $20.81 \%$ \\
\hline MARINE POLLUTION BULLETIN & 32 & $21.14 \%$ \\
\hline CHEMOSPHERE & 32 & $21.47 \%$ \\
\hline JOURNAL OF CHEMICAL THERMODYNAMICS & 31 & $21.79 \%$ \\
\hline JOURNAL OF CHEMICAL AND ENGINEERING DATA & 31 & $22.11 \%$ \\
\hline EUROPEAN JOURNAL OF OPERATIONAL RESEARCH & 31 & $22.43 \%$ \\
\hline $\begin{array}{l}\text { INTERNATIONAL JOURNAL OF SYSTEMATIC AND EVOLUTIONARY } \\
\text { MICROBIOLOGY }\end{array}$ & 30 & $22.75 \%$ \\
\hline ENGINEERING STRUCTURES & 29 & $23.05 \%$ \\
\hline INTERNATIONAL JOURNAL OF PHARMACEUTICS & 28 & $23.34 \%$ \\
\hline HYDROBIOLOGIA & 28 & $23.63 \%$ \\
\hline ELECTROCHIMICA ACTA & 28 & $23.92 \%$ \\
\hline FORENSIC SCIENCE INTERNATIONAL & 27 & $24.20 \%$ \\
\hline ENVIRONMENTAL TOXICOLOGY AND CHEMISTRY & 27 & $24.48 \%$ \\
\hline JOURNAL OF ELECTROANALYTICAL CHEMISTRY & 24 & $24.73 \%$ \\
\hline EUROPEAN PHYSICAL JOURNAL A & 24 & $24.98 \%$ \\
\hline BRADLEYA & 24 & $25.23 \%$ \\
\hline
\end{tabular}

Source: Science Citation Index, Thomson Reuters 
Table 2: Authors access to the titles used for publication (2004-2013)

\begin{tabular}{|c|c|c|c|}
\hline Source Titles & Library & B-On & $\mathrm{OA}$ \\
\hline PHYSICAL REVIEW D & $\mathrm{Y}$ & $\mathrm{N}$ & $\mathrm{N}$ \\
\hline JOURNAL OF PHYSICAL CHEMISTRY A & $\mathrm{Y}$ & $\mathrm{Y}$ & $\mathrm{N}$ \\
\hline PHYSICAL REVIEW C & $\mathrm{Y}$ & $\mathrm{N}$ & $\mathrm{N}$ \\
\hline $\begin{array}{l}\text { NUCLEAR INSTRUMENTS METHODS IN PHYSICS RESEARCH } \\
\text { SECTION A ACCELERATORS SPECTROMETERS DETECTORS } \\
\text { AND ASSOCIATED EQUIPMENT }\end{array}$ & $\mathrm{Y}$ & $\mathrm{Y}$ & $\mathrm{N}$ \\
\hline PHYSICS LETTERS B & $\mathrm{Y}$ & $\mathrm{Y}$ & $\mathrm{N}$ \\
\hline PLOS ONE & $\mathrm{N}$ & - & $\mathrm{Y}$ \\
\hline ACTA MEDICA PORTUGUESA & $\mathrm{N}$ & - & $\mathrm{Y}$ \\
\hline PHYSICAL REVIEW B & $\mathrm{Y}$ & $\mathrm{N}$ & $\mathrm{N}$ \\
\hline JOURNAL OF INSTRUMENTATION & $\mathrm{N}$ & $\mathrm{N}$ & $\mathrm{N}$ \\
\hline JOURNAL OF PHYSICAL CHEMISTRY B & $\mathrm{Y}$ & $\mathrm{Y}$ & $\mathrm{N}$ \\
\hline EUROPEAN PHYSICAL JOURNAL C & $\mathrm{Y}$ & - & $\mathrm{Y}$ \\
\hline $\begin{array}{l}\text { ACTA CRYSTALLOGRAPHICA SECTION E STRUCTURE } \\
\text { REPORTS ONLINE }\end{array}$ & $\mathrm{N}$ & - & $\mathrm{Y}$ \\
\hline PHYSICAL REVIEW LETTERS & $\mathrm{Y}$ & $\mathrm{N}$ & $\mathrm{N}$ \\
\hline IEEE TRANSACTIONS ON NUCLEAR SCIENCE & Y & $\mathrm{Y}$ & $\mathrm{N}$ \\
\hline ELECTROANALYSIS & $\mathrm{N}$ & $\mathrm{Y}$ & $\mathrm{N}$ \\
\hline JOURNAL OF CHEMICAL PHYSICS & $\mathrm{Y}$ & $\mathrm{Y}$ & $\mathrm{N}$ \\
\hline SURFACE COATINGS TECHNOLOGY & $\mathrm{N}$ & $\mathrm{Y}$ & $\mathrm{N}$ \\
\hline REVISTA PORTUGUESA DE CARDIOLOGIA & $\mathrm{N}$ & - & $\mathrm{Y}$ \\
\hline ACTA REUMATOLOGICA PORTUGUESA & $\mathrm{N}$ & - & $\mathrm{Y}$ \\
\hline ESTUARINE COASTAL AND SHELF SCIENCE & $\mathrm{Y}$ & $\mathrm{Y}$ & $\mathrm{N}$ \\
\hline TRANSPLANTATION PROCEEDINGS & $\mathrm{Y}$ & $\mathrm{Y}$ & $\mathrm{N}$ \\
\hline PHYSICAL CHEMISTRY CHEMICAL PHYSICS & $\mathrm{Y}$ & $\mathrm{Y}$ & $\mathrm{N}$ \\
\hline LINEAR ALGEBRA AND ITS APPLICATIONS & $\mathrm{Y}$ & $\mathrm{Y}$ & $\mathrm{N}$ \\
\hline JOURNAL OF HIGH ENERGY PHYSICS & $\mathrm{Y}$ & - & $\mathrm{Y}$ \\
\hline ECOLOGICAL INDICATORS & $\mathrm{N}$ & $\mathrm{Y}$ & $\mathrm{N}$ \\
\hline JOURNAL OF MOLECULAR STRUCTURE & $\mathrm{N}$ & $\mathrm{Y}$ & $\mathrm{N}$ \\
\hline REVISTA PORTUGUESA DE PNEUMOLOGIA & $\mathrm{Y}$ & - & $\mathrm{Y}$ \\
\hline CHEMICAL PHYSICS LETTERS & $\mathrm{Y}$ & $\mathrm{Y}$ & $\mathrm{N}$ \\
\hline LANGMUIR & $\mathrm{Y}$ & $\mathrm{Y}$ & $\mathrm{N}$ \\
\hline JOURNAL OF NEUROCHEMISTRY & $\mathrm{Y}$ & $\mathrm{Y}$ & $\mathrm{N}$ \\
\hline TETRAHEDRON & $\mathrm{Y}$ & $\mathrm{Y}$ & $\mathrm{N}$ \\
\hline PROGRESS OF THEORETICAL PHYSICS & $\mathrm{Y}$ & - & $\mathrm{Y}$ \\
\hline INDUSTRIAL ENGINEERING CHEMISTRY RESEARCH & $\mathrm{Y}$ & $\mathrm{Y}$ & $\mathrm{N}$ \\
\hline MARINE POLLUTION BULLETIN & $\mathrm{N}$ & $\mathrm{Y}$ & $\mathrm{N}$ \\
\hline CHEMOSPHERE & $\mathrm{Y}$ & $\mathrm{Y}$ & $\mathrm{N}$ \\
\hline JOURNAL OF CHEMICAL THERMODYNAMICS & $\mathrm{Y}$ & $\mathrm{Y}$ & $\mathrm{N}$ \\
\hline JOURNAL OF CHEMICAL AND ENGINEERING DATA & $\mathrm{N}$ & $\mathrm{Y}$ & $\mathrm{N}$ \\
\hline EUROPEAN JOURNAL OF OPERATIONAL RESEARCH & Y & $\mathrm{Y}$ & $\mathrm{N}$ \\
\hline $\begin{array}{l}\text { INTERNATIONAL JOURNAL OF SYSTEMATIC AND } \\
\text { EVOLUTIONARY MICROBIOLOGY }\end{array}$ & $\mathrm{Y}$ & $\mathrm{Y}$ & $\mathrm{N}$ \\
\hline ENGINEERING STRUCTURES & $\mathrm{Y}$ & $\mathrm{Y}$ & $\mathrm{N}$ \\
\hline INTERNATIONAL JOURNAL OF PHARMACEUTICS & $\mathrm{N}$ & $\mathrm{Y}$ & $\mathrm{N}$ \\
\hline HYDROBIOLOGIA & $\mathrm{Y}$ & $\mathrm{Y}$ & $\mathrm{N}$ \\
\hline ELECTROCHIMICA ACTA & $\mathrm{Y}$ & $\mathrm{Y}$ & $\mathrm{N}$ \\
\hline FORENSIC SCIENCE INTERNATIONAL & $\mathrm{Y}$ & $\mathrm{Y}$ & $\mathrm{N}$ \\
\hline ENVIRONMENTAL TOXICOLOGY AND CHEMISTRY & $\mathrm{Y}$ & $\mathrm{Y}$ & $\mathrm{N}$ \\
\hline JOURNAL OF ELECTROANALYTICAL CHEMISTRY & $\mathrm{Y}$ & $\mathrm{Y}$ & $\mathrm{N}$ \\
\hline EUROPEAN PHYSICAL JOURNAL A & $\mathrm{Y}$ & $\mathrm{Y}$ & $\mathrm{N}$ \\
\hline BRADLEYA* & $\mathrm{N}$ & $\mathrm{N}$ & $\mathrm{N}$ \\
\hline Total of articles & 1716 & 1461 & 518 \\
\hline
\end{tabular}

* Available in other institutions to co-affiliated authors. 
Table 3: Summarized publisher policy information from the SHERPA/RoMEO database as of July 2015

\begin{tabular}{|l|l|l|l|}
\hline RoMEO color & Archiving policy & Publishers & \% \\
\hline Green & Can archive pre-print and post-print & 723 & 36,9 \\
\hline$\underline{\text { Blue }}$ & Can archive post-print (i.e. final draft post-refereeing) & 661 & 33,7 \\
\hline$\underline{\text { Yellow }}$ & Can archive pre-print (i.e. pre-refereeing) & 128 & 6,5 \\
\hline$\underline{\text { White }}$ & Archiving not formally supported & 448 & 22,9 \\
\hline
\end{tabular}

Summary: $\mathbf{7 7 , 1 \%}$ of publishers on this list formally allow some form of self-archiving.

Source: (SHERPA/RoMEO Statistics for the 1960 publishers in the RoMEO database) 
Table 4: Journal policies regarding copyright and self-archiving, according to Sherpa/Romeo classification

\begin{tabular}{|l|l|l|l|}
\hline Sherpa/Romeo Classification & Titles & Articles & $\%$ \\
\hline Green & 28 & 1431 & $58.86 \%$ \\
\hline Yellow & 3 & 92 & $3.78 \%$ \\
\hline White & 6 & 342 & $14.07 \%$ \\
\hline Ungraded & 2 & 48 & $1.97 \%$ \\
\hline Open Access (OA) & 9 & 518 & $21.31 \%$ \\
\hline Green+OA & 37 & 1949 & $80.17 \%$ \\
\hline
\end{tabular}


Table 5: Observed self-archiving in the institutional repository of articles published in Green journals

\begin{tabular}{|l|l|l|}
\hline Self-archiving in Estudo Geral & Articles & $\%$ \\
\hline Not archived & 1104 & $77.15 \%$ \\
\hline Metadata only & 0 & $0.00 \%$ \\
\hline Preprint & 6 & $0.42 \%$ \\
\hline Post print (accepted manuscript) & 21 & $1.47 \%$ \\
\hline Publisher's copy & 300 & $20.96 \%$ \\
\hline
\end{tabular}

